\title{
What role does gender have in shaping knowledge that underpins the practice of midwifery?
}

\begin{abstract}
Midwifery is an ancient profession that continues to be practiced almost exclusively by women. This paper explores the role that millennia of gender exclusivity has had in shaping the knowledge that informs the profession. Prior to the Renaissance this knowledge was exclusively female, largely oral, tacit and intuitive whilst recognising childbearing as an important transformative period in a woman's lifecycle. Male scientific enquiry in the seventeenth century into human anatomy extended to women's bodies and childbirth and disrupted the female ways of knowing. Their positivist ontology focussing on the mechanics of childbirth created an opportunity for intervening in a normal process and receiving payment for it. The perceived structural superiority of a male obstetric ontology of childbirth has posed an existential threat to the midwifery profession. This paper concludes by discussing how $20^{\text {th }}$ century professional regulation of midwifery has encouraged midwives to use patriarchal structures and frameworks of knowledge to co-exist within the hegemonic biomedical model advocated by the majority of their obstetric colleagues.
\end{abstract}

Keywords: midwifery; intuition; knowledge; obstetrics; expert opinion; profession; ontology; epistemology

\section{Introduction}

It has been argued that midwifery is one of the oldest recorded professions which, prior to the end of the $16^{\text {th }}$ century, was performed exclusively by women (Donnison $\&$ Macdonald, 2017, p. 24) and millennia of gender exclusivity led to a distinct midwifery knowledge. However, there has been a dramatic paradigm shift in ontological and epistemological assumptions that have underpinned knowledge around childbirth over the past three centuries as a result of male scientific enquiry (Donnison, 1988, p. 23). This paper will adopt a social constructionist approach to explore the historical and 
social contexts of how midwifery knowledge in the Western world is informed by gender (Burr, 2015, p. 4). The discussion is focused on midwifery within the United Kingdom (UK) with a view to drawing parallels with the situation in other industrialised nations. It will begin by identifying the relationship between gender and power. It will then consider the uniquely female context of tacit midwifery knowledge before addressing how male involvement in the childbearing arena discredited this by representing itself as authoritative knowledge. It will conclude by positing the theory that the two ontological and epistemological positions have been able to co-exist through the advent of professionalisation and feminist discourse from the beginning of the $20^{\text {th }}$ century to the present day.

\section{Gender and power}

The author is motivated to explore this subject as he is a male midwife embarking on doctoral studies exploring the experiences of men in the midwifery profession and is seeking to understand how the intersection of gender with professional identity can inform the creation of knowledge.

The relationship between gender and knowledge is an important and rich area for exploration because gender has become inextricably bound up with notions of authoritative knowledge. One of the most influential of $20^{\text {th }}$ century social theorists, Foucault (1980) posited the theory that knowledge and power are inseparable concepts. He believed that 'discourses', or bodies of knowledge, are constantly challenged by alternative discourses because they offer access to power. The fact that the act of childbearing is exclusively the domain of women offers no protection from gendered discourses of power, indeed arguably it makes it more vulnerable to them given the patriarchal nature of western society. This is evidenced by the fact that in midwifery's 
allied profession of nursing, men are disproportionately more likely to assume managerial positions and in a shorter time period than their female counterparts (Wilson, 2003, p. 17) despite constituting only 11 percent of the workforce in the UK (Nursing \& Midwifery Council (NMC), 2018). To explore the epistemologies that underpin these metanarratives is important because philosophical enquiry can allow the individual to make 'arguments explicit' (Walliman, 2011, p. 58). This then allows the reader to critically evaluate literature within the context of its creation and 'unmask' (Fahy, 2008, p. 5) and challenge the dominant discourses of what Foucault (1979) terms 'disciplinary power' so that new knowledge can begin to take shape. This paper will argue that, viewed from a feminist perspective, the shift of midwifery from being exclusively the domain of women has led to it becoming subordinate to male dominant patriarchal -views of what counts as knowledge to improve outcomes in childbirth.

\section{Female knowing}

Historical midwifery knowledge, insomuch as it had an ontological and epistemological basis, has come to be defined as the inverse of the coordinated, documented and inductive knowledge of the realist discourse that followed it. Prior to the $17^{\text {th }}$ century midwifery knowledge was oral and confined to the isolated practices of individuals. Intuition, experience, embodied knowledge, ideas, emotions, religious teaching and accepted cultural norms have informed practice (Donnison \& Macdonald, 2017). Attempting to critically evaluate the efficacy of these female ways of knowing within the dominant contemporary discourse of 'evidence-based practice' is problematic. Women were excluded from universities and seats of 'learning' where knowledge was written in Latin by men for men and, as Green (2008, p. 495) suggests, within academic discourse only when knowledge is written down in a book does it acquire authority. Scholarship until the second half of the $19^{\text {th }}$ century was exclusively male in practice 
and midwifery education did not start to become a graduate profession until the $1990 \mathrm{~s}$ (Macdonald, 2017, p. 80).

In the absence of contemporaneous written accounts of historical midwifery practice, it is still possible to gain an insight into how birth practices might have looked prior to male involvement in birth by looking at recent anthropological accounts of cultures where midwifery is practised free from the influence of western biomedicine and mandatory professional regulation. Jordan (1997, p. 60) observed midwives at work in Yucatan, Mexico and concluded that women from the community and family worked alongside the midwife to support the parturient woman. Decision making was collective, collaborative and non-hierarchical, developed through shared experiences and stories, arguably based on intuitive knowledge. Intuition has been defined as knowing something without conscious reasoning but a key component of midwifery decision making (Barnfather, 2013). The fact that it has no obvious rational explanation which can be verbalised, written down and then open to challenge using accepted forms of (male) academic discourse renders it invalid as a form of knowledge within the biomedical paradigm. It has been suggested that intuition cannot be divorced from scientific enquiry given that it is often the very impetus to explore and test scientific theories (Davis-Floyd \& Davis, 1997). Others have argued that intuition is tacit knowledge, increasing with experience and multiple exposures to similar events. Angeli \& Campbell (2017) develop this argument further to suggest that being in the presence of a patient and having contact with them allows healthcare providers to be alert earlier to altered health states and then start investigating how to 'translate' this sense into accepted medical terminology, masking the embodied (female) origin of knowledge. Midwives are defined even in the Old English origins of their name as being 'with (mid) 
woman (wif)', often over a prolonged period of time and historically were embedded within the community they served. They are therefore uniquely privy to a way of knowing that is not accessible through the pervasive patriarchal authoritative knowledge framework.

\section{Male enquiry}

The advent of men into this exclusively female world came about as a result of the Renaissance, the $17^{\text {th }}$ century movement where male scientific enquiry into the world of anatomy extended to women's bodies and childbirth. A new positivist ontological assumption emerged supported by an epistemology of scientific enquiry and empiricism (Braun \& Clarke, 2013, p. 27) that sought to explain and thus control the process of labour. It has been widely argued in key texts (Wilson, 1995; Cahill, 2000; Donnison, 1988) that this has led to a male understanding of childbirth as a depersonalised, mechanical process which could be expedited by developing instruments like the forceps (Wilson, 1995, p. 3). Marxist philosophy argues that in a capitalist industrialised society all social structures exist in order to benefit the economically dominant and powerful class (Jones \& Bradbury, 2018, p. 41). Viewed from this perspective, childbirth under the male gaze was an opportunity for generating revenue by speeding up a mechanical process.

Male obstetricians - who attended women only for the moment of birth itself discredited intuition because it did not share these same ontological and epistemological assumptions. Realism is a philosophy of knowledge that believes in one absolute truth or reality which is discoverable given the right set of circumstances. What genders this knowledge is twofold: Firstly, scientists and philosophers who expounded this belief, unlike their antecedents, were exclusively male and therefore had no intrinsic 
motivation or embodied experience to offer an alternative or complementary perspective to this ontological position. Secondly the emphasis on an understanding of anatomy and physiology learned through dissection originates from the desire to cure illness and pathology which served to benefit male authority by remunerating it for this knowledge. These positionalities run counter to the philosophy of midwifery that childbearing is both a transformative social event and a normal physiological process (International Confederation of Midwives, 2014).

In the $20^{\text {th }}$ century, the culture of risk management and a biomedical model of childbearing as a result of a positivist ontology with a focus on pathology has resulted in technological dominance of women's bodies. This has taken the form of disembodied scientific observation both internally via ultrasound scans to visualise the structures of the developing fetus and externally with fetal cardiotocography to monitor fetal heart activity. This has had the effect of rendering the woman herself invisible by emphasising the personhood of the fetus (Kingdon, 2009, p. 103). Furthermore, it has been argued that the efficacy of these technologies is scientifically unevaluated (Cahill, 2000). It has also been established that less than twenty percent of guideline recommendations by the Royal College of Obstetricians and Gynaecologists are based on empirical evidence with most of the recommendations deriving from 'expert opinion' (Prusova et al., 2014). Therefore, what has come to be accepted in the $21^{\text {st }}$ century as authoritative knowledge around childbirth poses an existential challenge to the positivist ontology from which it evolved. It is recognised within the rules of scientific enquiry that expert opinion is vulnerable to bias and the uniqueness of pregnancy makes it ethically challenging to gather empirical evidence in the form of 
randomised controlled trials. It is ironic then that 'experiential knowledge' so devalued in midwifery has unwittingly come to be the dominant form of knowledge in obstetrics.

\section{Professionalisation and co-existence}

Following the narrative arc of this essay, a logical conclusion would be that midwifery in the UK should soon cease to exist in direct correlation with the increasing dominance of a male obstetric ontology of childbirth. Trends in place of birth corroborate this hypothesis - at the beginning of the $20^{\text {th }}$ century the "vast majority of women delivered at home' (McIntosh, 2012, p. 37) under the care of the midwife whereas currently 98 percent of births in England and Wales take place in hospitals rather than in private domestic spaces (Office for National Statistics, 2017) where care is led by obstetricians. The ascendancy of authoritative knowledge by definition does not allow for a multiplicity of differing types of knowledge co-existing with equal status. Structural superiority and efficiency (Jordan, 1997, p. 56) which are hallmarks of patriarchy ensure that other types of knowledge are devalued.

The continued existence of midwifery in the United Kingdom can be traced back to the Midwives Act of 1902. This created an exclusively female profession regulated by the exclusively male medical profession. In order to maintain the work of women supporting other women, midwives needed to lobby parliament to recognise their work as a 'profession' and thus inhabit the structures and values set up by male institutions characterised as having a set body of knowledge typically gained from an academic institution (Hunt \& Symonds, 1995, p. 18), as well as accountability to a regulatory body with a set of ethical principles. Viewed from a Marxist epistemology, midwifery knowledge, in order to exist in any form at all, had to be circumscribed by male medical 
knowledge which consequently would benefit the economically dominant and powerful class (Jones \& Bradbury, 2018, p. 41).

And yet there has been a debate about whether midwifery should ever even be considered a profession. Traditionally professions have been limited to the three 'learned professions' of law, theology or medicine (O’Day, 2007). Thus, professions have become defined as the ruling authorities on determining what is absolute or true for society as a whole and this truth can only be tested and challenged within the selfserving philosophical frameworks that they have devised. Until the $20^{\text {th }}$ century these were exclusively male preserves. With the rise of women in the workplace in the second half of the $20^{\text {th }}$ century, traditionally female occupations requiring training and regulation such as teaching, nursing and midwifery became termed 'semi-professions' (Hunt \& Symonds, 1995, p. 19). Distancing midwifery from being recognized as a full profession supports Ehrenreich \& English's (1974, p. 40) view that professions are elitist and sexist in order to preserve power for the few to have influence over the majority. Nevertheless, despite the dominance of patriarchal biomedical practices, the professionalisation - semi or whole - of midwifery has allowed it to exist. Many rapidly industrialising nations have experienced a doubling in caesarean section rates this century to over $50 \%$ of all births (Betran et al., 2016) and in the United States birth can no longer be thought of as a 'nonmedical' event due to the disappearance of a midwifery voice (Inhorn, 2006, p. 355). Whilst midwifery exists in name, whether it has a distinct knowledge is still the subject of ongoing debate. Walsh (2006) asserts that much of the focus for midwives has become the extrinsic epistemology of midwifery as a practice of 'doing' (task orientated) at the expense of the intrinsic ontology of midwifery or the experience of 'being' (holism). 


\section{Towards a new understanding}

A tradition of 'conflict writing' emerged alongside the second-wave of feminist theory which sought to expose the social and cultural context of patriarchal dominance over women's bodies (McIntosh, 2012, p.9). A binary position was presented with pre-17th century knowledge as holistic, intuitive and inherently female whilst post-enlightenment knowledge was patriarchal, technocratic and male in origin. The result has been, in recent years, an emphasis on developing midwives who are able to 'challenge' guidelines and practices which are not woman-centred (Macdonald, 2017, p. 81) by adopting the dominant male discourse to protect the historical female midwifery ways of knowing.

This essay has adopted both essentialist and socially constructed understandings of gender and sought to understand how the synergy of both concepts has influenced the production of knowledge to support the childbearing process. It has distinguished midwifery as both philosophically and essentially female and obstetrics as male. In the $21^{\text {st }}$ century it is timely to re-examine this approach. Cultural constructs of gender have legitimised the acceptability of women providing the emotion work of childbirth whilst men 'fix it' when it 'goes wrong'. But it is women who now dominate both professions, constituting nearly two thirds of UK obstetricians (General Medical Council, 2016, p. 35) as well as over 99.5 percent of the midwifery workforce (NMC, 2018). The myopic focus of the female body as faulty or dangerous and therefore to be fixed allowed men to focus on the technical aspects of childbirth divorced from it being a continuum of the act of procreation. It is to be hoped that this return to a majority body of female caregivers can consciously reconsider the 'hegemony of the evidence 
paradigm in determining the boundaries of [midwifery] knowledge' (Walsh \& Evans, 2014) and encompass a multiplicity of ontologies and epistemologies that will benefit both caregivers and parturient women.

Acknowledgements

With thanks to Dr Mary Dobson and Professor Jackie Campbell for their support, critical review and comments

References:

Angeli, E. \& Campbell, L. (2017) Intuition in healthcare communication practices: initial findings from a qualitative inquiry. Professional Communication Conference (ProComm), 2017 IEEE International, 1-6.

Barnfather, T. (2013) Can intuitive knowledge be taught in midwifery practice? British Journal of Midwifery, 21 (2), 131 - 136

Betran, A., Ye, J., Moller, A., Zhang, J., Gulmezoglu, A. \& Torloni, M. (2016) The increasing trend in caesarean section rates: Global, regional \& national estimates: 19902014. PLoS ONE, 11 (2):e0148343. https://doi.org/10.1371/journal.pone.0148343

Braun, V. \& Clarke, V. (2013) Successful qualitative research: a practical guide for beginners. London: SAGE

Burr, V. (2015) Social constructionism ( $3^{\text {rd }}$ ed). London: Routledge 
Cahill, H. (2000) Male appropriation \& medicalization of childbirth: an historical analysis. Journal of Adult Nursing, 33 (3), 334-342

Davis-Floyd, R. \& Davis, E. (1997) Intuition as authoritative knowledge in midwifery and home birth. In: Davis-Floyd, E. \& Sargent, C. (eds.) Childbirth \& authoritative knowledge: Cross-cultural perspective. Berkeley, CA: University of California Press

Donnison, J. (1988) Midwives \& medical men: A history of the struggle for the control of childbirth ( $2^{\text {nd }}$ ed). London: Historical Publications

Donnison, J. \& Macdonald, S. (2017) A history of the midwifery profession in the United Kingdom. In: Macdonald, S. \& Johnson, G. (eds.) Mayes' midwifery (15 ${ }^{\text {th }}$ ed). Edinburgh: Elsevier

Ehrenreich, B. \& English, E. (1974) Witches, midwives \& nurses: A history of women healers. London: Compendium

Fahy, K. (2008) Power and the social construction of birth territory. In: Fahy, K., Foureur, M. \& Hastie, C. (eds.) Birth territory \& midwifery guardianship: theory for practice, education \& research. Edinburgh: Elsevier

Foucault, M. (1979) Discipline \& punish: the birth of the prison. New York, NY: Vintage Books

Foucault, M. (1980) Power/knowledge: Selected interviews. New York, NY: Pantheon 
General Medical Council (2016) The state of medical education and practice in the UK. London: General Medical Council

Green, M. (2008) Gendering the history of women's healthcare. Gender \& History, 20 (3), $487-518$

Hunt, S. \& Symonds, A. (1995) The social meaning of midwifery. Basingstoke: Macmillan

Inhorn, M. (2006) Defining women's health: a dozen messages from more than 150 ethnographies. Medical Anthropology Quarterly, 20 (3), 345-378

International Confederation of Midwives (2014) Core document: Philosophy \& model of midwifery care. International Confederation of Midwives [online]. Available from: https://www.internationalmidwives.org/assets/files/definitions-files/2018/06/engphilosophy-and-model-of-midwifery-care.pdf [Accessed 15th December 2018]

Jones, P. \& Bradbury, L. (2018) Introducing social theory ( $3^{\text {rd }}$ ed.). Cambridge: Polity Press

Jordan, B. (1997) Authoritative knowledge and its construction. In: Davis-Floyd, E. \& Sargent, C. (eds.) Childbirth \& authoritative knowledge: Cross-cultural perspective. Berkeley, CA: University of California Press 
Kingdon, C. (2009) Sociology for midwives. London: Quay Books

Macdonald, S. (2017) The midwife as lifelong learner. In: Macdonald, S. \& Johnson, G. (eds.) Mayes' midwifery (15 ${ }^{\text {th }}$ ed.). Edinburgh: Elsevier

McIntosh, T. (2012) A social history of maternity \& childbirth: key themes in maternity care. London: Routledge

NMC (2018) The NMC register. London: NMC

O'Day, R. (2007) Social change in the history of education: Perspectives on the emergence of learned professions in England, c.1500 - 1800. Journal of the History of Education in Society, 36 (4-5), 409 - 428

Office for National Statistics (2017) Birth characteristics in England \& Wales:2016. Office for National Statistics [online]. Available from:

https://www.ons.gov.uk/peoplepopulationandcommunity/birthsdeathsandmarriages/live births/bulletins/birthcharacteristicsinenglandandwales/2016 [Accessed 6th December 2018]

Prusova, K., Churcher, L., Tyler, A. \& Lukugamage, A. (2014) Royal College of Obstetricians \& Gynaecologists guidelines: How evidence-based are they? Journal of Obstetrics \& Gynaecologists, 34 (8), 706-711

Walliman, N. (2011) Your research project ( $3^{\text {rd }}$ ed.). London: SAGE 
Walsh, D. (2006) The ontology of childbirth. British Journal of Midwifery, 14 (11), 662

Walsh, D. \& Evans, K. (2014) Critical realism: an important theoretical perspective for midwifery research. Midwifery, 30, e1-e6

Wilson, A. (1995) The making of man-midwifery: childbirth in England, 1660-1770.

London: UCL Press

Wilson, F. (2003) Organizational behaviour and gender (2 ${ }^{\text {nd }}$ ed.). Aldershot: Ashgate 